\title{
Population weights in the international order
}

\section{Geoffrey McNicoll}

Population Council

Follow this and additional works at: https://knowledgecommons.popcouncil.org/departments_sbsr-pgy

Part of the Demography, Population, and Ecology Commons, Family, Life Course, and Society Commons, and the International Public Health Commons How does access to this work benefit you? Let us know!

\section{Recommended Citation}

McNicoll, Geoffrey. 1999. "Population weights in the international order," Policy Research Division Working Paper no. 126. New York: Population Council. Version of record: https://doi.org/10.1111/ j.1728-4457.1999.00411.x 


\title{
Q Population Council
}

Policy Research Division Working Paper No. 126 (1999)

\author{
Population Weights in the International Order
}

Geoffrey McNicoll

Geoffrey McNicoll is Professor, Demography Program, Australian National University and Senior Associate, Policy Research Division, Population Council. 


\begin{abstract}
Population relativities play little part in the international system. A nation's economic and military power is influenced by population size, but as one factor among many. Formal relations among states exclude population from consideration by the principle of sovereign equality. Three sources of possible change in this situation are explored, in which states would be "population-weighted" to a greater degree than before. Convergence of productivity levels around the world, expected by many, would bring the economic and population rankings of states more into line. Such convergence is occurring, but selectively and for the most part quite slowly. Anticipation of its effect, however, influences the international order well in advance. A second source of change is the necessity to allocate among states the use of global commons, particularly the atmosphere as a sink for greenhouse gases. Acceptable remedies for this and perhaps other environmental spillovers are likely to involve at least in part a per capita allocation. And third, population weights are implicitly more prominent in futures in which states are less important-as in envisaged scenarios of global civil society.
\end{abstract}

This material should not be reproduced without written permission from the author. 
Two principles chiefly govern the relationships among states. One is the reality (or, more strictly, the perception) of relative power-economic and military, isolated or in alliance. The other is the convention of the sovereign equality of states. The structure of the United Nations echoes these principles, with the Security Council in conception a concert of great powers, and the General Assembly a concert of all. The Council embodies a realist view of peacekeeping, albeit the realities of half a century ago, with a provision (Article 12) in the Charter ensuring that the Assembly can only deal with matters that the Council has not preempted. The Assembly embodies the European doctrine of state sovereignty, its one-state one-vote rule surviving as membership expanded from 51 in 1945 to 185 today.

A striking characteristic of this international system is that almost nothing in its forms or functions acknowledges the massive disparities in population size among its members. For nearly all comparative purposes, per state or within-country per capita measures prevail.

Of course, such neglect of population may reflect true inconsequence, with size effects swamped by other considerations. Thus a state's economic weight and military strength are linked more to technological capacity and institutional design than to population numbers. And sovereign equality has plausibly been a useful conceit for the great powers in manufacturing coalitions on particular issues, while able to be brushed aside when and where national interests requirethough it is less clear why the demographic heavyweights play along with the conceit. But a residue of demographic import should surely have remained. Like the dog that didn't bark, the absence of population weights in the international order is a curiosity worth exploring. The question has more than academic interest if the situation has now begun to change-if there are forces at work tending to raise the salience of such weights.

In this essay I will examine the reasons that population has not had much of a place thus far in the modern era of international relations, and try to gauge what place it will have in the future.

\section{RELATIVE POPULATION SIZES: TRENDS AND IMPLICATIONS}

Some broad-brush demographic data are needed as background. The overall picture of population change in recent decades is familiar. In poor nations, rapid declines in mortality led to high population growth rates, often judged to be onerous and sometimes unsustainable; declines in fertility (and in a few places, resurgent mortality) are now bringing those rates down again, thereby "solving" the population "problem." In rich nations - and in others that have experienced rapid fertility declines - very low fertility and rising longevity have been enlarging the proportions of the elderly, a process set to continue and even quicken in the future. And between poor and rich

nations, migration flows persist at or somewhat beyond the level permitted by the political barriers of the recipients. 
Population size does not figure prominently in this picture. Demographers' attention is mainly to rates of change and components of change-the frontiers for prediction and policy action-rather than to absolute or relative numbers. But for the present purpose the latter magnitudes are central. They define the international demographic landscape that existed on the eve of the industrial era and record its transformation. Nations that industrialized early emerged from their mortality and fertility transitions with a two- or threefold increase in population. Many of the latecomers will have experienced a six- or eightfold increase. Moreover the transformation does not end in universal replacement-level fertility and (eventual) constancy of population: with the entrenchment of very low fertility, many countries contemplate a literal withering away under successive generational falls in population size-perhaps of 20 percent or more-or radical alteration of identity under mass immigration.

The effect of these changes on regional population shares is shown in Table 1, summarizing the situation over the last two centuries and a forecast for the next 50 years. There was a substantial increase in the population share of Europe and North America in the nineteenth century as mortality yielded to improved living standards, education, and public health. The relative population size of the industrializing "West," broadly construed, increased from about one-fifth of the world's population in 1800 to one-third by 1900. Subsequently, as mortality declines spread to Latin America, Asia, and Africa, creating the modern population "explosion," this proportion steadily fell, passing 17.5 percent in 2000, a share not seen (if the murky estimates can be credited) since the fifteenth century in the aftermath of the Black Death. UN forecasts show the proportion dropping to 12 percent by 2050 .

Asia's population share, probably more than two-thirds of world population over much of human history (McEvedy and Jones 1978: Part 6), drops appreciably over the nineteenth century, then part-recovers as its own demographic transition gets underway. The region's widespread fertility decline in the decades following World War II cut back the rate of growth, holding its global share to about 60 percent. In Africa, population growth probably increased early in the twentieth century with rising fertility, and accelerated with the later falls in mortality. Resulting rapid growth has produced a fast-rising population share. While there are some recent signs of fertility dropping, the $1998 \mathrm{UN}$ medium forecast is for a 20 percent share by 2050. (The AIDS epidemic is taken into account in this projection, although its course and demographic impact are speculative.) 
Table 1: Population distribution by major world region, estimates and projections, 18002050 (percent)

\begin{tabular}{|c|c|c|c|c|c|c|c|}
\hline \multicolumn{2}{|c|}{ Region } & 1800 & 1850 & 1900 & 1950 & 2000 & 2050 \\
\hline \multicolumn{2}{|c|}{ Europe $^{a}$} & 20 & 23.7 & 27.5 & 21.7 & 12.0 & 7 \\
\hline \multicolumn{2}{|c|}{ US, Canada, Australia, NZ } & 1 & 2.4 & 5.5 & 7.2 & 5.5 & 5 \\
\hline \multicolumn{2}{|c|}{ Latin America } & 2 & 2.5 & 4.1 & 6.6 & 8.6 & 9 \\
\hline \multicolumn{2}{|c|}{$\operatorname{Asia}^{\mathrm{b}}$} & 69 & 64.7 & 56.7 & 55.7 & 60.9 & 59 \\
\hline \multicolumn{2}{|l|}{ Africa } & 8 & 6.7 & 6.1 & 8.8 & 13.0 & 20 \\
\hline \multirow[t]{2}{*}{ World } & (percent) & 100 & 100.0 & 100.0 & 100.0 & 100.0 & 100 \\
\hline & (billions) & $(0.90)$ & $(1.18)$ & $(1.56)$ & $(2.52)$ & $(6.05)$ & (8.9) \\
\hline
\end{tabular}

The perspective on these long-run trends in relativities that sees them as a restoration of the North-South status quo ante clearly has some validity. Amartya Sen, noting that the UN forecasts imply that by 2050 "the Asians and the Africans would return to being proportionately almost exactly as numerous as they were before the European industrial revolution," remarks that "the sense of a growing 'imbalance' in the world...implicitly presumes that the expansion of Europeans earlier on was natural, whereas the same process happening now to other populations unnaturally disturbs the 'balance'" (Sen 1994: 63). Yet the idea of a global political demography is itself a modern development, so that comparisons with a preindustrial era, while arithmetically incontestable, are anachronistic. The trends of the last and next half-centuries are not tracing a shift back in time but creating a genuinely new demographic order.

One dimension of that order is the number of people entering the young labor force ages-that is, the number of those requiring inclusion as adult participants in the economy and society. A rough calculation is given in Table 2. The time trends show Western countries peaking in the 1970s, after which the number of entrants has been static or declining. In Asia and Latin America the numbers grow rapidly to around 2000. In Africa, no plateau is evident within this time frame. The changing regional distribution shows the large labor force shift toward the South in the past half-century, and the much more modest future pace of change.

The exceptional situation of Africa is exemplified by looking at the absolute increase in the younger part of the labor force-aged population, say the age group 20-40 years-the ages also of peak mobility. The increase in this group over the period from 1975 to 2000 and as forecast for 2000-2025 is estimated as follows (in millions, United Nations 1999-medium variant): 


\begin{tabular}{lcc}
\hline & $\mathbf{1 9 7 5 - 2 0 0 0}$ & $\mathbf{2 0 0 0 - 2 0 2 5}$ \\
\hline Africa & 117 & 196 \\
Rest of world & 669 & 202 \\
\hline
\end{tabular}

Over the next 25 years (and possibly well beyond) Africa will be dealing with increases in its youthful population comparable to those of the rest of the world combined. Its delayed fertility decline and continued high (and with AIDS, even rising) mortality defer the aging problems that other regions will be confronting, but do so at a heavy economic and human cost.

Table 2: Absolute annual numbers of entrants to labor force ages ${ }^{\mathrm{a}}$ by major world region, estimates and projections, 1950-2050 (millions)

\begin{tabular}{|c|c|c|c|c|c|}
\hline Region & 1950 & 1975 & 2000 & 2025 & 2050 \\
\hline Europe $^{\mathrm{b}}$ & 9 & 11 & 10 & 7 & 6 \\
\hline US, Canada, Australia, NZ & 3 & 5 & 4 & 5 & 5 \\
\hline Latin America & 3 & 6 & 10 & 11 & 11 \\
\hline Asia $^{c}$ & 27 & 46 & 66 & 70 & 66 \\
\hline Africa & 4 & 8 & 16 & 26 & 29 \\
\hline World & 46 & 76 & 106 & 119 & 117 \\
\hline
\end{tabular}

Crude comparisons of population or potential labor force lump together groups of vastly different levels of skill and effectiveness. More refined comparisons might look at, say, those with completed secondary or higher education, as a means of capturing levels of human capital. But the further we take such refinements, the nearer we get to making comparisons among sizes of economies—workers weighted by their productivity—rather than size of populations.

The time trends in population shares given in Table 1, while important in themselves, are not the only or even the main potential source of change in demographic influence on the international order. More important are shifts in the salience of demographic differences that already exist. Salience is chiefly affected by economic growth—especially "growth with equity," which raises the consumption of the average person and not merely average consumption. But the salience of demographic differences can also be affected by shifts in environmental systems and in perceptions of international inequality. In each of these cases the international effect may be felt far more quickly than through the comparatively stolid pace of population change. 


\section{DEMOGRAPHIC INCONSEQUENCE: INEQUALITIES OF POWER}

In international relations theory power is defined either in terms of the economic and military capabilities of states or as the ability to command or influence the actions of otherswhether directly or by setting the rules of the game (Rothgeb 1993). However, the distinction between the two-between power-as-resources and power-as-contro—-is somewhat blurred: a state with large resource-based capabilities is in a position to persuade, if necessary by threat or coercion: it must be listened to. Hence even if an analysis of power is conducted using the second definition, the first is necessarily a background presence as well.

What determines a state's capabilities? The ingredients presumably include size of economy, population, and territory, technological level, size and equipment of armed forces, and such qualitative attributes as organizational effectiveness and morale-what some development economists once referred to as Xefficiency. There have been numerous attempts to construct empirical indices of power, combining measures of such factors. These indices are quite strongly intercorrelated, as would be expected, and correlated too with subjective perceptions of power by informed respondents (see Sullivan 1990 for a discussion). Thus population is a usual ingredient in the ranking, but does not dominate.'

Population was not always deemed just one factor among many. The mercantilist doctrine dominant in early modern Europe took for granted that state power, like state prosperity, was linked to population size and enhanced by population increase. This was manifested in conquest and colonization of distant territories and in restrictions on emigration and farfetched pronatalist policies at home. ${ }^{2}$ With comparable levels of productivity most countries had a share of gross world product roughly proportional to their populations. As late as 1820, by Angus Maddison's estimates, the six countries with the largest populations-China, India, Russia, Japan, France, and Britain —also had the largest economies. Britain, the most advanced economy of that period, had a product just two and a half times its proportional share, France about twice (Maddison 1995: 30; in the 1990s the equivalent multiple for the most advanced industrialized countries was about four). But China's economy was five times the size of Britain's or France's, and India's was three times their size.

With the industrial revolution and the ascendancy of Smithian liberal economic theory, demography's place was reassessed. National productivity levels steadily diverged, selectively advantaging one state over another. Except where there were abundant natural resources, rapid population growth came to be seen as likely to lead to impoverishment, as Malthus argued, though a moderate rate of increase was held by most (including Smith and Malthus) to signal economic health and vigor. Trade, industrial development, and technological prowess, and the education and organizational skills to promote and utilize them, were increasingly recognized as the routes to economic —and thereby military—strength. An open international trade regime, even a partial and 
highly imperfect one, or free-trade pacts with more or less willing partners, could overcome the limitations of a small domestic market for states with the requisite agility and adeptness.

A kind of demographic competition nevertheless persisted, seen in the nineteenth-century empires. The populations of these multinational entities, along with their natural resources and sheer geographic extent, contributed to metropolitan power and status. Crude mercantilist rationales for empire did not vanish with the industrial revolution but were supplemented by developmentalist ones: colonial lands and peoples were extensions of the agrarian hinterland and, increasingly, markets for burgeoning manufactures. Kingsley Davis (1974), employing an expansive definition, identified 17 colonial powers in place in 1900. Together with their colonies they accounted for 92 percent of the world population. Three of these, Britain, France, and the Netherlands, themselves 5 percent of the world's population, nominally controlled 34 percent of it. Davis's estimates of the 1900 population size ranking of the ten largest political entities (population size of metropolitan powers plus colonies, in millions, with proportions in colonies in parentheses) are as follows (Davis 1974: 14):

$\begin{array}{lrrlrr}\text { Britain } & 441 & (91 \%) & \text { Germany } & 68 & (17 \%) \\ \text { China } & 434 & (6 \%) & \text { Japan } & 47 & (6 \%) \\ \text { Russia } & 148 & (10 \%) & \text { Netherlands } & 41 & (87 \%) \\ \text { France } & 87 & (55 \%) & \text { Turkey } & 38 & (39 \%) \\ \text { United States } & 86 & (13 \%) & \text { Italy } & 33 & (3 \%)\end{array}$

What counts as a colony is partly in the eye of the beholder: in the UN debates on decolonization only overseas territories - the so-called saltwater empires-were at issue.

In the twentieth century, the end game of the imperial enterprise was not at first apparent. The industrialized states had been experiencing falling birth rates and, extrapolating into the future with the new conceptual weaponry of "intrinsic" growth rates, worried about actual population decline. Their fear of depopulation was not of collective marginalization in the world - as Davis (p. 62) points out, they believed that the poorer regions would grow very slowly because of continuing high mortality_but of weakness vis-à-vis each other. Industrialized states lacking colonies nonetheless claimed to be disadvantaged demographically as well as in status and economic opportunity. In debates on overpopulation in the 1930s they depicted a division of states into "haves" and "have-nots"—on the one hand, the "satisfied, well-provided, satiate, bourgeois, possessor nations," on the other, "the unsatisfied, unprovided, hungry, proletarian nations" (André Touzet 1937, quoted in F. C. Wright 1939: 20). The difference being described was not that between developed and less developed countries: the possessions referred to were colonies - as markets for industry, suppliers of raw materials, and outlets for emigration. The 
"principal victims of population pressure," by their own estimation, were Germany, Italy, and Japan. Their claim was for a reapportioning of colonies among metropolitan states.

In the aftermath of World War II not only were such transparent excuses for expansionist designs demolished but pressures to dissolve the existing empires became overwhelming. Over the next two decades new nation-states proliferated, though leaving an imperial remnant of economic and cultural links among them. While the status loss to the erstwhile metropolitan powers was appreciable, the anticipated economic losses turned out to be largely illusory. The economic benefits of empire, if there were any, could be retained, with few of the costs, through trade ties and preferential tariffs.

Over time imperial preference lost ground to simple geography, with trade pacts increasingly defined by region. Significantly, free trade did not imply free labor mobility: that distinction between a trade association and a common market was firmly preserved. Only in the European Union have there been efforts to create a single labor market and immigration policy. Attempts to establish worldwide free-trade rules, through GATT and WTO, were also underway. To the extent states see themselves as securely anchored in an international trade regime, market power is distanced from population size.

In the military arena, the place of the classic link between population and power, the significance of the population factor had steadily eroded in the industrial age, giving way to technological and organizational capabilities. Nuclear weapons at first sight seemed to have completed the process. Their development and possession has been a status marker in the international order separate from size of economy or population. Indeed, India's decision to join the nuclear club might be seen as a response to the lack of deference accorded to rank on those other dimensions - in particular, India's lesser international role in comparison to China's. ${ }^{3}$ In terms of the actual threat such weapons pose rather than the status they bring, large population size like large geographic extent did little to diminish vulnerability in an era of megacities.

But nuclear deterrence at the strategic level left substantial scope for conventionally armed forces. Here, while qualitative differences might ultimately be decisive, it could be argued that troop numbers, like territorial depth, still mattered. ${ }^{4}$ This was the case in the lengthy confrontation of NATO and Warsaw Pact forces in Europe. Western strategists pointed to the comparatively high fertility of the Central Asian republics as a source of Soviet Bloc strength in manning the Warsaw Pact divisions in Eastern Europe, in contrast to the difficulty of recruiting for the NATO divisions in West Germany from the low-fertility West. The worry in retrospect seems quaint - an aspect of the wider misjudgment of conditions in the Soviet Union, beset not only with gross organizational inadequacies but also with unresolved ethnic, linguistic, and nationality divisions. ${ }^{5}$ Demographic scale and dynamism, just as they need not coincide with economic strength, can be offset by societal weakness. 
Comparative demographic inconsequence was also seen in the formal institutions of the international system. A major institutional manifestation of state power in the twentieth century has been in the design of the peacekeeping functions of the League of Nations and the United Nations. The League's Council and the United Nations' Security Council essentially comprised the allied victors of the two world wars. In the case of the League this was spelled out in the Covenant, which identified the Council's five permanent members only as "the Principal Allied and Associated Powers" (Article 4). They were the United States, Britain, France, Italy, and Japan. ${ }^{6}$ (Four other members were to be selected by the Assembly.)

Nonparticipation by the United States and a growing list of withdrawals and expulsions reduced the League to near irrelevance well before its actual demise, but much of its design was transferred to the UN. The permanent members of the UN's Security Council were to be the "great powers." The Council would have other representation, but its actions would require unanimity on the part of the permanent members. At the 1944 Dumbarton Oaks conference the great powers were seen as the Big Four: the United States, Great Britain, the Soviet Union, and China. At the San Francisco conference the following year this became the Big Five, with France's inclusion.

The wartime alliance, expectations of postwar roles, and political calculation determined this membership; population size was at most a small consideration. China's inclusion, at US insistence, was not on grounds of population but in anticipation of a future Chinese peacekeeping role in Asia vis-à-vis Japan. Britain pushed for the addition of France, supposedly to lessen Soviet influence on European issues. US plans to include Brazil as a permanent member, the most plausible Latin American choice on grounds of size and great-power potential, encountered opposition from both the Soviet Union and Britain and were dropped. (See Hildebrand 1990: ch. 6.)

At Dumbarton Oaks, Britain suggested that larger states should serve more frequently on the Security Council, but retreated when the Soviet Union tied this proposal to the issue of UN membership for all 16 of its republics (Russell 1958: 444-two republics, Ukraine and Byelorussia, now Belarus, in addition to the USSR, were ultimately admitted). At San Francisco, India raised the same matter, proposing "that due regard also be paid to population and economic capacity in selecting nonpermanent members"; this too was defeated (ibid.: 648). The Charter as adopted acknowledged a need for the Council to have regional representation, but imposed no other criteria. It was to have 11 members, five of them, listed by name, permanent and vetoequipped.

Crispin Tickell, Britain's former UN ambassador, in remarking on the anomalous situation of a Security Council's permanent membership comprised of the victors in a war that ended over half a century ago, writes: "It is hard to think of new and satisfactory criteria to govern permanent 
membership. Geographical size? Size of population? Gross national product? Possession of nuclear weapons? Readiness to act, if necessary with military force, on behalf of the international community? Any choice bristles with difficulties" (Tickell 1998: 12). The anomaly thus remains.

\section{DEMOGRAPHIC INCONSEQUENCE: SOVEREIGN EQUALITY OF STATES}

The acceptance of the state as the effective unit of global social and economic interaction was the second crucial factor in the sidelining of population size in international affairs. The states system, a European invention, is usually dated from the 1648 Treaty of Westphalia that ended the Thirty Years' War. The state became, in James Mayall's phrase, "the most successful western export to the rest of the world" (Mayall 1990: 111). The characteristics of states that mattered most in interaction were, first, military and economic power and second, the mere fact of statehood - the recognition as such by other states. ${ }^{8}$ Their population size, except as it contributed to one or the other, did not count.

The doctrine of state autonomy appears to have proceeded from an analogy of the state with the person, in an era in which the moral equality of persons was coming to be accepted. Sovereignty now resided in the state rather than the leader, and nominally states were thus to be equals. (The colonial empires were initially viewed as states like others; only in the twentieth century did their status as single sovereign entities come under challenge.) The principle of noninterference among states, emerging in eighteenth century writings on international law, was then a corollary — an analogous property to the liberty of the individual (Beitz 1979: 71-76). International society, in turn, was one in which juridically equal states were the constituent units. ${ }^{9}$

Imperial dismemberment was foreshadowed in the listing of the UN's purposes, the second of which was "to develop friendly relations among nations based on respect for the principle of equal rights and self-determination of peoples" (Article 1), a phrasing proposed by the Soviet Union though a sentiment also endorsed by the United States (see Moynihan 1993: 93-94). The UN's designers would have foreseen the breakup of the remaining saltwater empires (if not the land empire of the USSR) and the coming independence of the principal colonial territories and their participation in the international system. However, they could hardly have anticipated the proliferation of states that in fact has taken place. That development called for an international security regime which incorporated strong expectations that state formation was a once-only event, with states, once recognized, secure within their borders against national "liberation" movements from within and expansionist or irridentist claims from outside. Such a regime gradually came into being, though its norms were by no means fully observed. Adoption of the principle of

national self-determination Mayall (1990: 56) sees as an effort "to freeze the political map in a way which has never previously been attempted"- an "unprecedented attempt to bring history to an end." National minority rights within states, a pressing issue for the League, did not appear on the 
UN's agenda - supplanted there by the less politically demanding endorsement of universal human rights (soon to be embodied in the Universal Declaration of Human Rights and later in its many extensions and elaborations) and the vague concept of self-determination. (See Simpson 1996: 39-42; Jackson Preece 1998: 106-110.)

Sovereign equality was not unqualified: in both the League and the UN it was confined to matters not concerned with security issues. But states with small populations were at least assured a voice - in the UN not only in the General Assembly and its Economic and Social Council, but also in many other international forums, notably the specialized agencies and the numerous international conferences the UN has organized on assorted global issues. (The principle was not applied where it might have mattered most: in the IMF and World Bank.) In the face of the postcolonial spawning of micro-states, it was simpler to let the principle prevail than to try to introduce a new class system of states. ${ }^{10}$

Noninterference was an explicit provision in the UN charter. Under it, the way was open for statehood of entities of a size that would hardly have dared aspire to that status before. Liechtenstein and San Marino were rebuffed for membership in the League of Nations in the 1920s; in the 1990s both were admitted to the United Nations (James 1992: 381n; their populations are each below 30,000). Palau, population 17,000, was admitted in 1994. Pitcairn Island, the refuge of the Bounty mutineers, though not a UN member, is identified as a statistically real political entity by UN agencies and the South Pacific Commission—which recorded its 1996 population as 47 persons. Even small colonial territories on acquiring independence mostly escaped annexation by larger neighbors-Goa being an early exception, Hong Kong and Macau recent if less clear-cut ones; East Timor is still in play.

The UN's General Assembly is the chief arena for the display of sovereign equality. The many proposals for UN reform have much to say about Security Council membership but rarely suggest any rejigging of the Assembly. One exception is Clark and Sohn (1958), whose proposed revised UN charter called for population-weighted representation in a strengthened General Assembly. ${ }^{11}$ The Security Council would be replaced by a less powerful Executive Council, on which the four most populous states would always be represented and those in the next size-class would be half the time. Similar in spirit is a more recent proposal by Segall (1991) for a "Second Assembly" within the UN, an "Assembly of Peoples," with voting proportional to population except for some safeguards for small nations - a model also noted by the Commission on Global Governance (1995). ${ }^{12}$ (See also Archibugi and Held 1995.)

The existing size distribution of Assembly members, who would vote on the matter, clearly makes any such radical Charter reform highly improbable. As of 1998, well over half of UN member states (109 out of 185) have populations below 10 million; 37 are below 1 million, 11 below $100,000 .{ }^{13}$ The small states presumably would mot countenance the loss of influence that 
weighted voting would bring. The overall shift in voting balance toward the South generated by continuing state formation and one-nation one-vote has worked against the specific influence of population size. India and Indonesia became the sovereign equals of Bhutan and Brunei rather than great powers in waiting.

Formal organizational design cannot in the end determine a state's influence. Powerful states can corral reluctant allies on issues that matter to them, by generalized pressure or direct side-payments, and if that proves tiresome or ineffective they have a de facto option of exit: they can shrug off Lilliputian efforts to trammel them and conduct their business elsewhere. The relative importance of one-nation one-vote organizations has arguably diminished over time in comparison to those that better reflect power differentials. ${ }^{14}$ International organizations, over the years, compete for functional dominance like slow-growing trees in a forest. UN agencies dominated by poor countries (ILO, FAO, WHO, UNESCO, and later additions, especially UNCTAD) lost out in authority and effectiveness to the Bretton Woods institutions and GATT (and its successor, WTO), dominated by the rich—and to agencies wholly outside the UN system, like OECD, OSCE, the International Energy Agency, and the regional trade and security pacts. But while realism in international relations was thereby preserved against the inroads of one-nation one-vote, the salience of population weights was not increased.

\section{REASSERTION OF POPULATION WEIGHTS}

The world order depicted above is one where population size is only loosely tied to the hierarchy of power among states, and not at all to the fact of membership in international society. This is both too simple and too static a picture. In regional international relations, population size does seem to identify most of the heavyweight actors. The rules of the global game are perhaps out of touch with some emerging realities. Among the forces for change in the international system that need to be factored in are those making for political and economic convergence. To the extent that technological trends are lessening international productivity differentials, there will be some convergence in population-based and economy-based rankings of states. To the extent that there is an emerging world market, increasingly in the hands of nonstate actors to whom consumers are identified by preferences and purchasing power rather than by geography or nationality, stateness is subordinated to market demographics. In later sections I will consider a further range of forces for change: environmental and normative.

"A population of 100 million or more today is not sufficient to confer superpower status upon a nation," Hedley Bull has remarked, "but it is widely thought to be necessary for this status" (Bull 1987: 79). In 1998, this group of states numbered ten (United Nations 1999: xvii): 


$\begin{array}{ll}\text { China } & 1256 \text { million } \\ \text { India } & 982 \\ \text { United States } & 274 \\ \text { Indonesia } & 206 \\ \text { Brazil } & 166 \\ \text { Pakistan } & 148 \\ \text { Russian Federation } & 147 \\ \text { Japan } & 126 \\ \text { Bangladesh } & 125 \\ \text { Nigeria } & 106\end{array}$

Mexico (97 million) is barely outside the group; within 20 years Ethiopia, Philippines, and Vietnam will also likely be included, and the Democratic Republic of Congo, Egypt, and Iran are in line a few years later. The European Union, already acting as a single economy for many purposes and as a single political entity for a few, would rank third on the list if treated as a state-like entity. Its 15 member states had a 1998 population of 375 million (European Commission 1998: 121).

If "superpower status" is broadened to cover regional "pivotal" or hegemonic powersstates that provide collective goods, in particular through assumption of the role of security manager, in their region (see Ayoob 1999) — then only Bangladesh and Pakistan of the 1998 "bigten" would not qualify. Moreover, Pakistan, though lacking a hegemonic region (beyond Afghanistan), should perhaps be accorded some status both as an overt nuclear power and as (Ayoob's term) "regional spoiler" in South Asia. Indonesia, beyond its current economic difficulties, is likely to retain an effectively managerial if not hegemonic role in Southeast Asia. ${ }^{15}$ Of the countries in the demographic wings, Vietnam and Iran are probably the most plausible hegemon aspirants or potential spoilers.

Is this population-linked status a consequence of newfound economic strength-that is, of narrowed economic differentials? In aggregate terms at least, it would appear not. The wide disparity between economic and demographic country rankings can be read directly from estimates of labor productivity. Maddison (1995: 47) has made estimates of GDP per hour worked relative to US productivity for selected countries, but his results are virtually the same as the more readily available purchasing power parity estimates of relative per capita GNP. Using the World Bank's data for 1997 (World Bank 1999), these are as follows for the ten largest countries $(\mathrm{US}=100)$ :

$\begin{array}{lr}\text { China } & 12 \\ \text { India } & 6 \\ \text { United States } & 100 \\ \text { Indonesia } & 12 \\ \text { Brazil } & 22\end{array}$




$\begin{array}{lr}\text { Pakistan } & 6 \\ \text { Russian Federation } & 15 \\ \text { Japan } & 81 \\ \text { Bangladesh } & 4 \\ \text { Nigeria } & 3\end{array}$

The four large European Union states (Germany, France, United Kingdom, Italy) are clustered in the range $70-76$.

Time trends in per capita GDP for broad world regions are given in Table 3, again relative to the highest-income region (essentially, the US). Measuring from the 1950s, Western Europe is clearly converging to the United States, and Southern Europe and Asia are improving from a much lower base. But Latin America has been marking time and Africa regressing over the period. If comparisons are made with the estimated relativities at the beginning of the century, there is scant sign of convergence at all.

Table 3: Patterns of convergence in the world economy: Real GDP per capita, by region, 1900 and 1950-90 (indexes: US and other "Western offshoots" = 100)

\begin{tabular}{|c|c|c|c|c|c|c|c|c|}
\hline \multirow[b]{2}{*}{ Year } & \multicolumn{2}{|c|}{$\begin{array}{c}\text { US and other } \\
\text { "Western offshoot" }\end{array}$} & \multirow{2}{*}{$\begin{array}{c}\text { Western } \\
\text { Europe }\end{array}$} & \multirow{2}{*}{$\begin{array}{c}\text { Southern } \\
\text { Europe }\end{array}$} & \multirow{2}{*}{$\begin{array}{l}\text { Eastern } \\
\text { Europe }\end{array}$} & \multirow{2}{*}{$\begin{array}{c}\text { Latin } \\
\text { America }\end{array}$} & \multirow[b]{2}{*}{ Asia } & \multirow[b]{2}{*}{ Africa } \\
\hline & (1990 US\$) & (Index) & & & & & & \\
\hline 1900 & 4,022 & 100 & 76 & 39 & 34 & 27 & 17 & 12 \\
\hline 1950 & 9,255 & 100 & 55 & 22 & 28 & 27 & 8 & 9 \\
\hline 1960 & 10,813 & 100 & 71 & 26 & 34 & 28 & 10 & 9 \\
\hline 1970 & 14,372 & 100 & 77 & 35 & 36 & 27 & 11 & 9 \\
\hline 1980 & 17,782 & 100 & 80 & 37 & 35 & 29 & 12 & 8 \\
\hline 1990 & 21,261 & 100 & 81 & 38 & 30 & 22 & 14 & 6 \\
\hline
\end{tabular}

Note on regions: other "Western offshoots" are Canada, Australia, and New Zealand; Southern Europe includes Turkey; Eastern Europe includes former USSR; Asia includes Pacific islands.

Source of data: Maddison (1995): Table G-3.

China would often be taken as an exception, where economic catch-up has been proceeding apace. But that is a very recent situation. At the beginning of the twentieth century China's economy was five times the size of Japan's, and not much below that of the United States; by the 1970s, after decades of relative decline, it was about equal to Japan's and one-third the size of the U.S. (Maddison 1995: Appendix C). China was by far the weakest of the Big Four allies in World War II, and its postwar economic development was derailed by the calamitous episodes of the Great Leap Forward and the Cultural Revolution. That it would become a major economic power became likely only with the Dengist reforms of the late 1970s and 1980s, which freed up the rural economy and created a vigorous manufacturing sector (boosted statistically by the adoption of purchasing power values in international comparisons of national accounts). Also 
assisting on this score was the evident fact that a potentially dire demographic predicament had been largely brought under control, with fertility halved over the 1970s. At economic growth rate differentials comparable to those experienced over the 1980s and 1990s, China's GDP will exceed that of the United States within a few decades.

Some narrowing of technological differences among states is an inevitable consequence of advances in education and communications in the laggard states and of a world economy relatively open to trade and capital flows - though the continued openness of the trade regime is by no means assured. Some "declinists" see a turnover among technological leaders as a natural course of events, the outcome perhaps of what Davis (1958: 211) called "a hardening of the sociological arteries" or the accumulation of Olson's (1982) "distributional coalitions." On the other hand, there is no reason to expect an approach to uniformity of technological levels around the world: working against this entropic tendency are the many factors making for increasing returns - in particular, economies of location and scale and network externalities. Such factors apply not just in production but also in research and development. At the other end of the distribution, low levels of social capital, pervasive physical insecurity, and government rent-seeking may be formidable obstacles to economic improvement. At the extreme, some states may find no accessible path of escape, forming a kind of underclass in the international arena.

Adding to the disequilibrating forces among states, according to some accounts, is the ability of the leading economic powers to set the rules of the game in international economic relations - the "architecture" of the financial regime, the forms of treaty and detailed provisions negotiated under the WTO, the conditionalities imposed on structural adjustment aid and debt relief, the compromises permissible on environmental protocols.

The economy-wide average productivity trends in Table 3 are in some respects misleading. In any developing country, economic growth, even the growth-with-equity of the East Asian exemplars, does not uniformly raise all boats. Parts of the economy are accorded high priority by government and given favored treatment, gaining from heavy investment and transfers of advanced technology. Other parts, more closely reflecting overall factor proportions, remain resolutely low-tech. For populous countries, high-technology enclaves may be substantial in sizeIndia's software industry, Brazil's aircraft industry, the defense-related industries of China and India-without having more than a modest effect on the economy as a whole. The development task, of spreading the productivity levels of those sectors across the economy, remains onerous and long-term. Expectations, however, may run well ahead of achievement and determine responses: a large population promises to become a large market. The prospect to others of access to such a market gives large countries considerable bargaining power in trade negotiations, a power that can be leveraged into other spheres. The anticipation of market size, despite low 
current purchasing power and nontariff barriers of all kinds, is enough to raise the salience of population weights for these countries.

Empirically, population size appears to have a modest but distinctly positive effect on economic growth; in particular, a small population (say, below 10 million) is somewhat of a disadvantage. ${ }^{16}$ This would suggest that economic development as a world-wide process would tend to accentuate rather than offset population weights. However, moves toward economic integration increasingly cloud this issue. No country except perhaps North Korea any longer contemplates autarkic development. Countries small and large seek to ensure secure access to foreign markets for their exports, usually through a formal trade pact. In such relationships, for reasons perhaps no more compelling than geographic neatness, regionalism has tended to prevail. Of course, free-trade arrangements among states at comparably low economic levels and competing in the same export markets are of limited help: they may have little substance beyond their acronyms (ECOWAS, CARICOM, SAARC,...). Real payoff comes from attachment to a grouping containing advanced economies—-principally, the EU or NAFTA. ${ }^{17}$

The EU case suggests there are potential gains to member states from closer integration than that of a free-trade association. For example, Europe's longstanding low fertility raises the prospect of states becoming weaker and more vulnerable through population decline and a steadily rising burden of old-age dependency. Integration may lessen that vulnerability-and obscures it at the national level within an elaborate network of transfers and coordinated social policy reforms. There are costs of integration too: immigration becomes an issue that has to be decided centrally, with loss of local political influence on a matter that has substantial effects on both local and national society. Even if it progressed no further toward federation, in the international arena the EU increasingly acts cohesively, with many of the demographic features of statehood. In effect, population and power have come together in a somewhat state-like entity. But this merely emphasizes the uniqueness of the EU. It is hard to imagine NAFTA progressing in that direction, let alone most of the other trade pacts. Geographic distance, cultural prickliness, and migration fears all tend to prevent economic alliances from deepening much beyond trade pacts. Indeed, fission is as familiar a process as fusion, splitting states and economies.

In sum, technological catch-up and market development provide one route for the reassertion of population weights. The economies of many of the largest developing states have been growing rapidly, with appreciable effect on the center of economic gravity in the world. In per capita terms, however, convergence with the forerunners is a distant prospect at best.

\section{DEMOGRAPHIC CLAIMS ON NATURAL RESOURCES}

Claims over natural resources could potentially be another means by which population weights attained greater salience. International differences in natural resources, it has been argued, 
are even more clearly "morally arbitrary" than the interpersonal differences in talents that formed the basis of the Rawlsian case for redistribution. Historical injustices in the acquisition of resources were rife. Thus Beitz (1979:141) asserts the principle (with some qualifications) that "each person has an equal prima facie claim to a share of the total available resources." This would be to proclaim population weights in a radical fashion. Indeed, national boundaries would in effect be suppressed for purposes of ethical calculation. Protests frequently heard about the supposed injustice of the North's disproportionate consumption of resources-or sometimes its consumption per se-are at bottom premised on some such notional claims. ${ }^{18}$

The ethical case for a per capita criterion in allocative decisions is complicated by differential population growth. Should a society that in effect has chosen to expend its resources in population expansion be advantaged in comparison to another that chose not to? ${ }^{19}$ Rarely, of course, is there any actual "choice," but the thought experiment remains. At issue is how the additional members of the society should be counted: as atomistic individuals or as part of the society_and the society's responsibility. Is population growth a fact of nature, continually presenting new realities for ethical consideration, or an implicit outcome of social choice? ${ }^{20}$

As a practical matter, major international redistribution of either resources or people is not in the cards. The world's terrestrial natural resources are effectively "owned" by the states in which they lie, thus associating them—or the royalties their exploitation can generate-with territorially defined populations. ${ }^{21}$ While disputes over territory still occur, for the most part international boundaries are fixed. The exceptions make the headlines, but prove the rule. A similar closure has taken place in demography. The blithe expectation of Alfred Sauvy (1975: ch. 13) that people would inevitably flow from densely populated countries into low-density ones even against the wishes and sovereignty of the recipient state, as if equalizing pressure in a gas, comes up against the fact that economic development anywhere leads to a concentration of population, irrespective of average density levels. Most of the landscape even in populous countries is sparsely settledincreasingly so as agricultural technology advances. The strong forces for international migration, economic and political rather than demographic, in the main generate flows to developed-country cities, not to wide open spaces.

But boundaries and sovereignty do not dispose of all international problems of resources. Trans-border resources need management and allocation: rivers and water catchments, artesian basins, oil reservoirs, migratory species, and so on. Damaging pollution such as acid rain poses an analogous problem. A negotiated resolution would usually rely in part on the body of international law and in part on the relative power of the parties. When many states have a potential interest in the problem, such as in the pollution of the Mediterranean, the complexity of the negotiating task is much greater. In the case of so-called global commons, in principle all states have an interest. 
The global commons are nonappropriated (not necessarily nonappropriable) resources, whether or not they have formally been declared by the UN to be part of the "common heritage of mankind" (res communis humanitatis). They comprise the unapportioned part of the world's surface-Antarctica, the oceans, and seabed resources; certain other kinds of resource such as parts of the electromagnetic spectrum, geostationary orbits, and the moon and "outer space"; and, most crucially, the atmosphere as a sink for greenhouse gases. If a particular commons can be appropriated, there is scope for its privatization. Or it may be subjected to a negotiated management regime. Or, what would often be the default case, it may continue to be degraded by negative environmental spillovers into it.

What is the basis for claims on global commons? One option would be a kind of "finders keepers" or "first come, first served" rule, analogous to squatter's rights on an open land frontier or the staking out of mining claims. The returns go to the technologically proficient and the entrepreneurially adept, essentially by part-privatization. Simple spillovers into an unregulated commons (the setting for Hardin's "tragedy of the commons") are also in a sense a de facto unilateral claim on that resource. Here, however, the analogy to squatter's rights is imperfect: the firstcomer's usufruct can itself be devalued by the actions of latecomers. For example, geostationary satellites or broadcast wavelengths must be sufficiently separated not to cause mutual interference. Yet most observers would probably not see first come-first served as passing any acceptable test of fairness. Indeed, an incidental consequence of the entrenchment of a world of sovereign states in the postcolonial era has been the effective precluding of unilateral privatizations of global commons: this would now be seen as nearly tantamount to one state annexing another's territory. (Collective choice of privatization is another matter.) Even Antarctica, the subject of some latter-day territorial claims, has reacquired quasi-commons status under the 1959 Antarctic Treaty, with the claims held in abeyance. An allocation of a commons based on population would seemingly better pass a fairness test. ${ }^{22}$

How have demographic weights fared in the cases of the two most important global commons, the oceans and the atmosphere? Consider them in turn.

\section{The oceans}

After a decade of extraordinarily complex negotiations pitting North against South, coastal states against the landlocked, and capitalist states against communist, the Third United Nations Convention on the Law of the Sea (UNCLOS III) was concluded in 1982. After the requisite number of ratifications it came into force in 1994. Its central provisions were recognition of exclusive economic zones for coastal states extending for 200 miles beyond their shores, and establishment of an International Sea-Bed Authority to control exploitation of deep seabed resources. 
The first outcome, entailing a radical shrinkage of the oceanic common heritage-in particular, with assignment to coastal states rather than to "mankind" of most of the world's fisheries and the great bulk of potentially recoverable offshore petroleum-was reached with full support of the South (see Krasner 1985: 232-235). The geographic fortuity of coastline length determined the winners in this vast privatization, differentiating among poor countries as well as rich. Remote island states, tiny in land area and population, were proportionately the greatest beneficiaries. Remarkably, the resulting shift in property rights almost immediately found widespread acceptance- by states that refused to ratify the treaty as well as by treaty supporters.

The envisaged International Sea-Bed Authority was a different matter. The Authority was to award mining leases in the remaining common heritage area and also to oversee mining on its own account. It was to be governed by an Assembly of all signatories to the treaty, with onenation one-vote. How its revenues would be allocated, should there be any, was not specified: Article 82 of the Convention speaks of "equitable sharing criteria," suggesting that some needsbased or per capita formula would presumably be devised.

At the time the Authority's design was negotiated it was assumed that seabed mining would generate large revenues, especially from metallic nodules. Weakening prices and technological difficulties have since eroded that prospect. But the structure and role of the Authority proved major obstacles to ratification of UNCLOS by the United States and many other developed countries. The statist assumptions and centralized procedures of the Authority, redolent of the ill-fated New International Economic Order, were at odds with ascendant neoliberal ideology. In particular, the requirement to share their technology with the Authority was anathema to the mining companies. (See Volger 1995: 50.) Subsequent modifications in design have been undertaken in an effort to make the seabed regime more acceptable to the major nonsignatories.

In terms of the present argument, the bottom line is simple. The outcome of this vast apportionment of resources was decided in the main by a one-state one-vote process, though with benefits assigned to the geographically fortunate and with extra-treaty concessions (political sidepayments) to the major maritime powers in line with realist international theory. Population weights did not enter explicitly, and may at best assume a minor role in any eventual allocative decisions of the Authority.

\section{The atmosphere}

After the oceans, there is one other major global commons to be apportioned: the atmosphere, in its role as a sink for greenhouse gases. The fact that the overall level of greenhouse gases has also to be negotiated, in a context of uncertain and contested effects, does not lessen the difficulty of the allocative problem. Since population size and population growth are evident 
factors in the level and rate of increase of greenhouse gas emissions (Bongaarts 1992), in this case there is much less likelihood that demography will be overlooked.

The Conference of the Parties set up under the UN's Framework Convention on Climate Change, reached at the 1992 "Earth Summit" in Rio de Janeiro (and as of 1999 ratified by 177 countries), is charged with designing a binding international treaty to limit greenhouse gas emissions. Its third meeting, in 1997, produced the Kyoto Protocol, agreed to by the 38 developed-country Rio participants though not yet in force. The protocol sets out target levels of emissions for each of these countries in 2010, negotiated in terms of a proportional reduction (in a few cases, an increase) in their 1990 emission levels. Since all the 38 are industrialized, the existing differences in total emissions reflect chiefly the variation in industrial composition and energy sources used, and the size of economy. With the exception of the former Soviet bloc states, the size of economy is roughly proportional to population. Thus the Kyoto scheme is to a first approximation population-weighted. ${ }^{23}$

There are many reasons to doubt that the Kyoto Protocol will be effective in its purpose. McKibbin and Wilcoxen $(1997,1999)$ enumerate them: chiefly, political resistance to the uneven incidence and unknown level of abatement costs by country entailed in a fixed target regime; the likely unacceptability if not infeasibility of the massive international transfers that permit trading would create; and the incentives for cheating or reneging. Yet the problem of stabilizing atmospheric composition is likely be seen as increasingly urgent-moreover, requiring action not only by the Kyoto signatories but also by the major developing countries which in the mediumterm future will become the largest emitters. Hence whatever form the Kyoto treaty eventually takes, a critical issue is what criteria are going to be applied to the emissions of China, India, Brazil, and the other emerging economic-demographic giants. The principal choices under discussion are a quota proportional to size of economy (Baumert et al. 1999) or one proportional to size of population (Meyerson 1998b). Mixed choices would also be possible. ${ }^{24}$

In Meyerson's preferred scheme a global trajectory of greenhouse gas emissions is translated into an annual benchmark of equal per capita emissions in every country. A country exceeding this level would then come under a permit trading system, its excess emissions required to be offset against below-benchmark emissions elsewhere. It is population-weighted over time and not just at an initial point. Notionally, at any given time each person on the planet would be carrying an equal emission entitlement. Differential population growth among states would be accommodated, with global emissions capped by the agreed trajectory: hence there is no inducement to curtail that growth. As with the Kyoto Protocol, there would be the problem of how to take account of other relevant factors in country emissions: the country location of polluting industries, the treatment of natural and plantation forest sinks, latitude and climate, and so on. 
Any emissions regime will create winners and losers among states, but it seems virtually certain that this global commons will be allocated among states, if it is effectively allocated at all, with strong consideration to population sze. If no formal allocation proves possible, or none without a negating amount of cheating, population size is still likely to influence the scale of national emissions, but the ultimate winners and losers will be determined more by geographic fortuity and economic adaptability. Technological and organizational capacity rather than demography will be an advantage in adaptation; how demography would intersect with geography in this default outcome cannot yet be seen.

Greater recognition of population weights in the area of resources and the environment, except to the extent it permits agreement that would not otherwise be attained, is not a recipe for better global outcomes for ecosystem stability or biological diversity. Environmentalist values appear to be suppressed-or at least dominated by more immediate concerns-through the course of industrial development, only emerging (or reemerging, if arcadian views of the past are justified) with postindustrial affluence. Thus the overall human impact on the planet, as measured for instance in the calculations of Vitousek et al. (1997), would not be lessened by reallocation of beneficiaries, and its ill-effects might well be worsened.

\section{INTERNATIONAL SOCIETY VERSUS COSMOPOLIS}

There is a third way by which population weights could come to count for more: by the retreat of the state, the entity that currently speaks for its citizenry in most global discourse. Such a retreat is widely discussed and often declared, though with little consensus on its desirability and almost none on the organizational forms that might replace the states system.

There are well-recognized forces tending to erode state sovereignty-or to induce responses that do so: cross-border phenomena, such as environmental spillovers, refugee movements, illicit trade, and criminal enterprise; competing nonstate actors such as NGOs, multinational corporations, and IGOs (intergovernmental organizations); and an increasingly dense web of treaty commitments specifying the rights of individuals irrespective of citizenship. ${ }^{25}$ Economic liberalism seeks to defeat nationalist constraints on the development of world markets, fields for old-style transnational corporations or new-style internet commerce (Omhae 1995; Luttwak 1998). Globalization of values and tastes complements and promotes the trend. Transnational nongovernmental organizations and networks of likeminded individuals form the first sinews of what is heralded as a future global civil society.

A global society, "cosmopolis" in the Kantian term, is one of individuals, civil society organizations of all kinds, and some form of world government. None of the constituent categories or organized groups in the society is privileged in the way that state citizenship is now. If states are left, it is "as performers of duties, not as holders of rights" (Zolo 1997: 66). In Falk's (1992: 227) 
account, this society would be created by "the new complexities of global interdependence and by the decentering of political and economic control," superseding the states system and its liberal, realist ideology.

Visions of cosmopolitan futures tend to be welfarist in design. Most globalists, according to Danilo Zolo (1997: 181), a trenchant critic, would like to see "a global political authority actively engaged in guaranteeing not only peace but also distributive justice, ecological balance, the safeguarding of human rights, demographic containment and economic development." The vision propounded in the 1992 Human Development Report is of that kind-"a sort of planetary welfare state," Zolo calls it, managed by a new Development Security Council within the UN (see United Nations 1992: ch. 5). An alternative, looser globalization is that sketched by economists in end-of-history mode, proclaiming convergence to the "Washington consensus" on free-market development in an increasingly borderless world economy. ${ }^{26}$ In either case, world orderists mostly take for granted that global civil society would be peaceable, democratic, and respectful of minority rights: dystopian alternatives are not considered cosmopolitan. ${ }^{27}$

By diffusing power and delinking it from the state, and by eroding the significance of statehood, a cosmopolitan society would tend to be population-weighted. It would not necessarily be so: power may simply be transferred to an unresponsive global bureaucracy, or to a new hierarchy of corporations and other organizations lacking the at-least-formal inclusiveness of the territorial states system. ${ }^{28}$ In fact, imagining what an effective and non-gerrymandered cosmopolitan democracy might look like is difficult_perhaps an indication of its improbability. The proposed Assembly of Peoples mentioned earlier hardly seems to qualify. The European Union's parliament may eventually be seen as a (small-scale) model, though for now it is only a vague presence, eliciting little interest even at elections, if by no means powerless.

Communalism is a basic problem for the design of democracy. Where literal borders are lacking or too distant, societies construct virtual ones of their own, the fault-lines of ethnicity and religion those most immediately to hand. The liberal project—of all relationships individualized, with recognition of economic but not communal forces - can be defeated by the fear of the differential population sizes of the parties as well as by the perceived injustice of existing economic differentials. Demographic advantage may consist in both power (at its most benign, market power) and the "ethical imperative" by which each person is accorded, rhetorically at least, equal weight.

Between the future global civil society of the world orderists and the continued statecenteredness of the political realists is a middle position: that of an increasingly complex global system with multiple levels of actors, state and nonstate. This was what Bull (1977) called "neomedievalism": a "modern and secular counterpart" of medieval Christendom, embodying "its central characteristic: a system of overlapping authority and multiple loyalty" (p. 254). ${ }^{29}$ States would lose 
authority both to devolved entities within them and to supra-state authority - the inhabitants of Glasgow, in his example, having political loyalties shared among Scotland, the United Kingdom, the European Union, and the UN. Territoriality is spread rather than much weakened in this model. The principle of subsidiarity it expresses allows for greater local autonomy and accountability. "Post-Westphalian communities" (Linklater's [1996] term), reflecting the "multiple identities and loyalties" of a world in which national sovereignty has been transcended, can acknowledge culturally defined populations (within or across nations) that find no voice in the states system.

While social relations can thus follow the contours of society more closely, the problem of representation is not necessarily resolved. Communal solidarity may be achieved, for whatever it is worth, but there is still a need for political administration at higher organizational levels to deal with larger regional issues, and population weights may be lost in the process of aggregation. Margaret Canovan (1996: 117-119), criticizing this separation of the communal and the political, sees the result as being "to further politicize communal identity, while depriving the political structure of the affective support it needs to be able to command allegiance." Indeed, she sees an EU-type regional structure gaining the authority and political power to act as a coherent unit only to the extent that it effectively becomes a nation-state, claiming that level of allegiance from its citizens: not in her view a likely prospect.

A more modest, current-EU-style economic integration, however, might prove to be an acceptable and viable endpoint of the process. A popular perceived manifestation of the cosmopolitan future is the spread and rising prominence of the so-called world middle classcomprised of those who have attained at least a moderate level of wellbeing and acquired values and aspirations that are no longer tied to locality and tradition, but influenced by, if not yet fully part of, an emerging globalized culture. Nathan Keyfitz (1976) sought to enumerate this category through its tangible possessions, pointing in particular to the large and growing international population of car-owners. ${ }^{30}$ An updated criterion might be people with internet connections: as yet these would form a somewhat narrower cross-national category, but one with a greater claim to cosmopolitan significance-closer to Robert Reich's (1994) "symbolic analysts," the technologically literate elite that is held to be relatively immune to the forces of deindustrialization. Internet access is relatively cheap in hardware and additional local infrastructure, and offers a more radical kind of cultural cosmopolitanism than the older media of film and television.

Full-fledged cosmopolitan democracy, peopled by world citizens, is not in the foreseeable future. Most states are losing some measure of authority in certain spheres-notably on human rights and some environmental issues_-but seem unlikely to "wither" very far. There may be greater organizational complexity, but as an overlay rather than replacement of the present system. ${ }^{31}$ Strong states are at an obvious advantage in safeguarding the interests of their citizens, even when this requires compromise and recognition of changing international norms. Weak states 
have scant authority in the first place, but their populations are anything but cosmopolitan. ${ }^{32}$ For the populous states among them, the cosmopolitan principle of equal moral consideration for each person can be invoked in leveraging increased state power in the international arena-which, indeed, may be an effective way of achieving a political outcome benefiting their citizens.

\section{CONCLUSION}

Demography has an egalitarian bias, just as it has an anthropocentric one. In it people are counted individually - identified with a few biological attributes such as age and sex. They are not weighted by incomes as they are in giving a total size of economy, nor merged into a single citizenry as they are for other kinds of statewise analysis. In a decidely inegalitarian world, this has left demography on the sidelines of international relations.

Is demography destiny in the global arena? The arguments I have reviewed would suggest a highly qualified affirmative: up to a point. It had been roughly true, allowing for some striking exceptions, until the uneven spread of industrialization created the patterns of international inequality of the last two centuries-complicated by the colonial enterprise and overlaid, for the last quarter of that period, by the alliance structures of the Cold War. But looking ahead, population relativities will again count for more: as the world's demographic giants gain in economic strength and influence; as environmental spillover problems worsen and remedies for them, to be acceptable, need to pass political muster for fairness; and as the states system adjusts to accommodate both devolutionary and globalizing change. Moreover, the demographic relativities of the future will differ from today's in the certain further diminution of the West-and, more generally, the North—giving still greater cause for a new international order. Beyond simple population numbers, there will be a lengthy period of regionally disparate age structures, reflecting the timing of fertility decline.

That is a realist outlook, foreseeing adaptation by states to all-but-tectonic forces. But realism might also foresee countervailing trends and responses-tending to preserve current international economic differentials, choosing adaptation over remedy in the face of a degrading or destabilizing global environment, and discovering that a world order need not be democratic and that globalization may preserve rather than disrupt the status quo. The demographic ascendency of Africa evident in current forecasts shows little sign of being accompanied by the political and economic development that would be needed to translate population size into global influence. Elsewhere too, the smooth social processes that underlie the expectations of economic and demographic change in the twenty-first century may simply not be borne out. A new clutch of winners, demographically nondescript, could emerge.

Is there any part here for deliberate design? The realist would expect the future international order to be a modification of the present system, with policy intentions affecting it only 
modestly and at the margins. Yet quite plausibly, it will be significantly shaped by the compromises arrived at in dealing with the greenhouse problem and other still unknown global threats. Those compromises will have to acknowledge both the realities of existing power differences and the moral claims of population weights. Such a balance is implied in Robert Keohane's (1998) call for research on "how to design international institutions that are not only competent and effective but also accountable, at least ultimately, to democratic publics." Unfortunately, no formal design process is likely to be able to smoothly accommodate the coming changes. As Canovan (1996: 139) puts it, "we cannot easily reconcile the commitment to build Jerusalem for all mankind with the defence of our own patch of firm ground"—-which, she adds, "may itself be subject to erosion." 


\section{Notes}

Comments from Martin Brockerhoff are acknowledged.

1 For Organski and Organski (1961: 12-13) it came close to dominating. "The size of its population is by no means the only determinant of a nation's ability to persuade, reward, punish, and use force. But it is surely one of the most significant, and indeed it has an important bearing upon the other determinants of power."

2 Jeremy Bentham (1843 [1798]) recounted, with appropriate scorn, examples from the "political pharmacopoeia" of pronatalist measures being advocated in Prussia in his time.

3 "Who, then, are the great powers now?" asked Hedley Bull in 1977. "At most, the United States, the Soviet Union and China are great powers: Japan is only a potential great power; and Western Europe, while it is not amalgamated in a single state, is not a power at all" (Bull 1977: 203-204). That China, close to its political and economic nadir, would be so judged, and India absent even in "potential," presumably owed much to their respective military and especially nuclear capabilities.

$4 \quad$ See Quincy Wright (1958: 266): "As states become more alike in technology and organization —as they will in a shrinking world-population may increase in importance as a measure of military power."

5 As late as 1988, a Pentagon report noted: "Manpower constraints will make it more difficult for NATO to maintain its current force structure, will make conventional force buildups and reduced reliance on nuclear weapons more difficult and expensive, and perhaps promote labor-saving military technologies." Among Soviet draftees, the proportion of Central Asians was projected to rise steadily. However, "past Soviet military experience and policies make it clear that this ethnic mix is seen as a problem" (US Department of Defense 1988).

6 The original draft Article 4 listed the "British Empire" as the Council member (see Walters 1952: 45), though India, the greater portion of the empire, was itself a League member. (Membership was open to "any fully self-governed State, Dominion or Colony.")

7 It remains, too, a perennial item for discussion. Since the early 1990s the General Assembly has had a characteristically titled Open Ended Working Group on the Question of Equitable Representation on and Increase in the Membership of the Security Council and Other Matters Related to the Security Council.

8 Statehood in the sense of recognition is robust against the erosion of most of the internal attributes of a state, as in the case of state failure. Jackson (1990) uses the term quasi-state in this sense.

9 Although accepted in Europe from the seventeenth century and as an abstract principle more generally, sovereign equality was not mentioned in the Covenant of the League of Nations. Japan 
had proposed that the Covenant say that members "endorsed the principle of the equality of nations and the just treatment of their nationals," but this was strongly opposed by the US, Australia, and New Zealand, who saw it as aimed at their discriminatory immigration policies (Walters 1952: 63). The UN Charter, however, is explicit: Article 2 asserts the "principle of the sovereign equality of all its members."

10 The proliferation of states has even helped cement this situation. As Bull and Watson (1984: 434) remark, "the leaders and governments of the new states and of those which recovered their independence have demanded that the most distinctive feature of the European sates system, namely the sovereignty and juridical equality of all member states, large and small, should be maintained and reinforced."

11 Clark and Sohn would have nations arrayed in seven size categories, each category with a specified number of votes. Those in the smallest category, below 0.5 million population, would each have one representative; those in the largest, above 140 million in 1957 (China, India, the Soviet Union, and the US), 30 representatives each. The size groupings would be adjusted over time so that the size of the Assembly stayed roughly constant, as with reapportionment in the US House of Representatives. (The Clark-Sohn charter prescribed decennial world censuses.)

12 With weighted voting the General Assembly would of course be Asia-dominated. Peterson (1986: 56) quotes Ali Mazrui's African perspective (from 1964) on such a prospect: "A few [Africans] might even settle for, as it were, two Sukarnos for every De Gaulle on almost every issue discussed in the United Nations since 1962."

13 The distribution is approximately log-normal, like the size distribution of firms (the analogy is pursued by Russett 1974). Of the 37 UN member states with populations below one million, two (Iceland and Luxembourg) were original members, eight joined in the 1960s, 15 in the 1970s, six in the 1980s, and six (all below 100,000) in the 1990s.

14 Krasner (1985: 269) speaks of "the extreme incongruity between national power capabilities and organizations in which each state has an equal vote," making for the declining role of such organizations.

15 Ayoob (1999) expresses skepticism that Southeast Asia can become a "regional society" distinct from the wider Asia-Pacific security region, with Japan, China, and the U.S. the dominant players. Note that in some regions countries with far smaller populations have significant reach in their neighborhoods. South Africa (39 million) is potentially a hegemon in southern Africa. Australia (19 million) wields some influence among the demographic minnows of the South Pacific.

16 See the discussion of scale economies and other demographic effects on productivity in McNicoll (1984: 197-201). A few states actively seek population growth for the sake of scale economies or market size. Malaysia (1998 population 21 million) is often cited as an example, with a target population of 70 million set by Prime Minister Mahathir in 1982-partly on the basis of the size of domestic market needed for an efficient automobile industry. ("Population and the 
size of the domestic market" 1983.) The UN's 1998 medium forecast for Malaysia in 2050 is 37 million, with a yearly growth rate then of 0.5 percent.

${ }^{17}$ Large subglobal trade blocs may prove to be a stable structure. Edward Luttwak (1998) sees a possible future of three mutually exclusionary blocs centered on the EU, NAFTA, and an as yet uncrystallized East Asian grouping. Alternatively, the system envisaged by the WTO may eventually provide a secure trade regime on a global scale.

18 Cf. the concept of a nation's "ecological footprint" introduced in recent work on population carrying capacity, and the percapita standard of a "fair Earthshare." See Wackernagel and Rees (1995).

19 The advantage could be still greater: anticipated population growth could be argued to be a reason for more generous allocations to high-growth states. Formally, an average birth brings with it a notional stream of descendants, growing at the population growth rate. The time-discounted sum of these descendants at time 0 , imputed to the original birth, makes that birth the equivalent of a larger number of births without descendants. For moderate levels of population growth, that number is about 1.3 at a discount rate of 5 percent, 4 at a discount rate of 1 percent. (See Arthur and McNicoll 1977: 117.)

20 The US National Academy of Sciences' 1986 report on population growth and development remarked on the ethical equivalence of consumption of nonrenewable resources by a big population over a few years or by a small population over many. Notionally, this choice is a potential factor in national decisions affecting future population size. (National Research Council 1986.)

21 Ownership is more contentious in the case of biological than inorganic resources. Environmentalists would typically prefer the concept of stewardship in referring to rare species or fragile ecosystems.

22 See Wijkman (1982) for a discussion of the subject. Wijkman argues for the separation of equity and management issues - in particular, for regimes where "rents are distributed at the conference table and user rights are allocated in the marketplace" (p. 525). He notes, however, that "there is no objective basis for determining the best distribution [of rents]" (p. 524). The Commission on Global Governance (1995: 336) would promote a population-weighted distribution by awarding to all people (among other rights, such as "participation in governance at all levels") the right of "equal access to the global commons." In line with this, the 1967 Outer Space Treaty describes space above the earth's atmosphere as the "province of all mankind," and the 1979 Agreement on the Moon and other Celestial Bodies calls for an "equitable sharing" of the benefits of exploitation among all state parties (Article 11) (Volger 1995: 102). No revenue benefits appear in prospect. The 1996 Outer Space Treaty declared space above the earth's atmosphere to be a res communis.

23 The original carbon-tax scheme envisaged tradeable emission permits for $\mathrm{CO} 2$ that would be initially issued to states on a per capita basis-see Grubb 1989. Note that Kyoto does not allow 
for differential population growth. The country ranking of target reductions per capita—one kind of indication of the compliance effort called for-is very different from the country ranking of total reductions. (See Meyerson 1998a.)

${ }^{24}$ McKibben and Wilcoxen (1999) have proposed an alternative non-Kyoto regime in which permit trading takes place only within countries, but at an internationally agreed price. The overall emissions reduction is not preset, but could be adjusted with experience and knowledge by altering the permit price. They argue that such a scheme passes a test of political acceptability that Kyoto conspicuously fails.

25 The strengthening of international institutions, and their greater intrusion into what once would have been matters of wholly domestic jurisdiction, need not be evidence of state erosion. As Janice Thompson (1995: 229-230) points out, by acting through multilateral institutions states may in effect be able to exercise sovereignty with less societal constraint than before. Internationalization is "commonly mistaken for the erosion of sovereignty," whereas it can be almost the reverse. On the other hand, IGOs themselves have become increasingly open to influence by international (chiefly Western-based) NGOs, a phenomenon most evident at the large $\mathrm{UN}$ conferences but also felt more routinely in the activities of the UN and its specialized agencies.

${ }^{26}$ Both designs have been criticized as threatening to flatten out societal differentiation. Zolo (1997: 153) sees a welfarist political order as entailing a "drastic reduction in the complexity and differentiation of the international system." Rajni Kothari (1997: 233, 242), foreseeing "globalization through the spread of a neoliberal mindset," decries "a global order built on the social erosion of diverse civil societies and shunting to the margins of existence ideas of individual freedom and primary bonds, of the pride and dignity that comes from belonging to a class or a community, a caste or a tribal ancestry."

${ }^{27}$ This bias is remarked on by Bull (1977: 291): "The advocate of world government makes the tacit assumption that it is his own moral and political preferences that will be embodied in it..."

${ }^{28}$ A generic problem for a non-state-based society is the proliferation in it of analogues of the gated community - privatized ways of maintaining security and privilege in situations where safeguards offered through the public sector are deemed inadequate-leaving many of those outside the gates unprotected. Consider the case of a present-day enterprise that does not recognize the authority of states: international organized crime.

${ }^{29}$ Interestingly, William McNeill (1984) also finds a medieval redolence in his imagined future: in this case, a new-old kind of social stratification that serves as a substitute for simple border controls in rationing demographic access and regulating socialization. The liberalism approached in the West in recent decades and espoused nearly universally he sees as a passing phase in world history.

${ }^{30}$ Using various consumption indices in addition to car ownership, Keyfitz (1976: 33) arrives at a rough figure of 600 million for the size of the world middle class in 1975, and finds it to have been 
growing since the 1950 s at a rate of 45 percent. At that rate, by 2000 it would be some 1.8 billion, about 30 percent of the world population.

${ }^{31}$ Demeny (1982: 219) argues that one reason that "the option for convergence into an integrated human society is likely to remain effectively out of reach" is population growth itself: "[I]t would be clearly implausible to assume that development paths that would have been open to a world numbering, say, 3 billion persons - the world total in 1960 - will also be open to a population three or four times that size."

32 This is particularly the case for quasi-states. Clapham (1995: 274), discussing "negative sovereignty" in Africa, writes of "an 'international relations' which consists, not in relations between one state and another, but in relations between states and those who seek to evade or sometimes displace them." 


\section{References}

Archibugi, D. and David Held (eds.). 1995. Cosmopolitan Democracy: An Agenda for a New World Order. Cambridge: Polity Press.

Arthur, W. Brian and Geoffrey McNicoll. 1977. "Optimal time paths with age-dependence: a theory of population policy," Review of Economic Studies 44: 111-123.

Ayoob, Mohammed. 1999. "From regional system to regional society: exploring key variables in the construction of regional order," unpublished paper (Michigan State University).

Baumert, Kevin, Ruchi Bhandari, and Nancy Kete. 1999. What Might a Developing Country Climate Commitment Look Like? Washington, DC: World Resources Institute.

Beitz, Charles R. 1979. Political Theory and International Relations. Princeton: Princeton University Press.

Bentham, Jeremy. 1843 [1798]. "Of population," in The Works of Jeremy Bentham. Edinburgh: William Tait. Volume 3. (Reprinted in Population and Development Review 21, no. 2 [1995].)

Bongaarts, John. 1992. "Population growth and global warming," Population and Development Review 18: 299-319.

Bull, Hedley. 1977. The Anarchical Society: A Study of Order in World Politics. London: Macmillan.

Bull, Hedley. 1987. "Population and the present world structure," in William Alonso (ed.), Population in an Interacting World. Cambridge, MA: Harvard University Press.

Bull, Hedley and Adam Watson (eds.). 1984. The Expansion of International Society. Oxford: Clarendon Press.

Canovan, Margaret. 1996. Nationhood and Political Theory. Cheltenham, UK: Edward Elgar.

Clapham, Christopher. 1995. Africa and the International System: The Politics of State Survival. Cambridge: Cambridge University Press.

Clark, Grenville and Louis B. Sohn. 1958. World Peace Through World Law. Cambridge, MA: Harvard University Press.

Commission on Global Governance. 1995. Our Global Neighbourhood. Oxford: Oxford University Press. 
Davis, Kingsley. 1958. "Population and power in the free world," in Philip M. Hauser (ed.), Population and World Politics. Glencoe, IL: Free Press.

Davis, Kingsley. 1974. "Population policy and international change." Unpublished manuscript, International Population and Urban Research, University of California, Berkeley. 119 p.

Demeny, Paul. 1982. "Population policies," in Just Faaland (ed.), Population and the World Economy in the 21st Century. Oxford: Blackwell.

European Commission. 1998. Agenda 2000: Financing the European Union. Brussels.

Falk, Richard. 1992. Explorations at the Edge of Time: The Prospects for World Order. Philadelphia: Temple University Press.

Grubb, Michael. 1989. The Greenhouse Effect: Negotiating Targets. London: Royal Institute of International Affairs.

Hilderbrand. Robert C. 1990. Dumbarton Oaks: The Origins of the United Nations and the Search for Postwar Security. Chapel Hill: University of North Carolina Press.

Jackson, Robert. 1990. Quasi-States: Sovereignty, International Relations and the Third World. Cambridge: Cambridge University Press.

Jackson Preece, Jennifer. 1998. National Minorities and the European Nation-States System. Oxford: Clarendon Press.

James, Alan. 1992. "The equality of states: contemporary manifestations of an ancient doctrine," Review of International Studies 18: 377-392.

Keohane, Robert O. 1998. "International institutions: can interdependence work?" Foreign Policy (Spring): 82-96.

Keyfitz, Nathan. 1976. "World resources and the world middle class," Scientific American 235, no. 1: 28-35.

Kothari, Rajni. 1997. "Globalization: A world adrift," Alternatives 22: 227-267.

Krasner, Stephen D. 1985. Structural Conflict: The Third World Against Global Liberalism. Berkeley: University of California Press.

Linklater, Andrew. 1996. "Citizenship and sovereignty in the post-Westphalian state," European Journal of International Relations 2: 77-103.

Luttwak, Edward. 1998. Turbo-Capitalism: Winners and Losers in the Global Economy. London: Weidenfield \& Nicolson. 
Maddison, Angus. 1995. Monitoring the World Economy 1820-1992. Paris: Organisation for Economic Co-operation and Development.

Mayall, James. 1990. Nationalism and International Society. Cambridge: Cambridge University Press.

McEvedy, Colin and Richard Jones. 1978. Atlas of World Population History. London: Allen Lane.

McKibbin, Warwick J. and Peter J. Wilcoxen. 1997. "Salvaging the Kyoto climate change negotiations," Brookings Policy Brief no. 27.

McKibbin, Warwick J. and Peter J. Wilcoxen. 1999. "Permit trading under the Kyoto Protocol and beyond," paper presented at the Conference on the Sustainable Future of the Global System, United Nations University, Tokyo.

McNeill, William H. 1984. "Human migration in historical perspective," Population and Development Review 10: 1-18.

McNicoll, Geoffrey. 1984. "Consequences of rapid population growth: An overview and assessment," Population and Development Review 10: 177-240.

Meyerson, Frederick A.B. 1998a. "Population, carbon emissions, and global warming: the forgotten relationship at Kyoto," Population and Development Review 24: 115-130.

Meyerson, Frederick A.B. 1998b. "Toward a per capita-based climate treaty: Reply," Population and Development Review 24: 804-810.

Moynihan, Daniel Patrick. 1993. Pandaemonium: Ethnicity in International Politics. New York: Oxford University Press.

National Research Council. 1986. Population Growth and Economic Development: Policy Questions. Washington, DC: National Academy Press.

Olson, Mancur. 1982. The Rise and Decline of Nations: Economic Growth, Stagflation, and Social Rigidities. New Haven: Yale University Press.

Omhae, Kenichi. 1995. The End of the Nation State: The Rise of Regional Economies. London: Harper Collins.

Organski, Katherine and A.F.K. Organski. 1961. Population and World Power. New York: Knopf.

Peterson, M.J. 1986. The General Assembly in World Politics. Boston: Allen \& Unwin. 
"Population and the size of the domestic market: a Malaysian view." 1983. Population and Development Review 9: 389-391.

Reich, Robert B. 1994. The Work of Nations. New York: Knopf.

Rothgeb, John M., Jr. 1993. Defining Power: Influence and Force in the Contemporary International System. New York: St Martin's Press.

Russell, Ruth B. 1958. A History of the United Nations Charter: The Role of the United States 1940-1945. Washington, DC: Brookings Institution.

Russett, Bruce M. 1974. Power and Community in World Politics. San Francisco: Freeman.

Sauvy, Alfred. 1975. Zero Growth? New York: Praeger.

Segall, J. 1991. "A UN Second Assembly," in F. Barnaby (ed.), Building a More Democratic United Nations. London: Cass.

Sen, Amartya. 1994. "Population: Delusion and reality," New York Review of Books 41, no. 15 (22 September): 62-71.

Simpson, Gerry J. 1996. "The diffusion of sovereignty: self-determination in the post-colonial age," in Mortimer Sellers (ed.) The New World Order: Sovereignty, Human Rights, and the Self-Determination of Peoples. Oxford: Berg.

Sullivan, Michael P. 1990. Power in Contemporary International Politics. Columbia, SC: University of South Carolina Press.

Thompson, Janice E. 1995. "State sovereignty in international relations: Bridging the gap between theory and empirical research," International Studies Quarterly 39: 213-234.

Tickell, Crispin. 1998. "The United Nations: Pressures for change," Global Society 12, no. 1: 513.

Touzet, André. 1937. Le Problème colonial et la Paix du monde. Paris: Sirey.

United Nations. 1992. Human Development Report 1992. New York: Oxford University Press.

United Nations. 1997. World Population Prospects: The 1996 Revision. New York.

United Nations. 1999. World Population Prospects: The 1998 Revision. New York.

US Department of Defense. 1988. The Future Security Environment. Washington, DC. Excerpted in Population and Development Review 15 (1989): 587-599. 
Vitousek, Peter M., Harold A. Mooney, Jane Lubchenco, and Jerry M. Melillo. 1997. "Human domination of Earth's ecosystems," Science 277: 494-499.

Volger, John. 1995. The Global Commons: A Regime Analysis. Chichester, UK: Wiley.

Wackernagel, Mathis and William Rees. 1996. Our Ecological Footprint: Reducing Human Impact on the Earth. Philadelphia: New Society Publishers.

Walters, F.P. 1952. A History of the League of Nations. London: Oxford University Press.

Wijkman, Per Magnus. 1982. "Managing the global commons," International Organization 36: 511-536.

World Bank. 1999. World Development Report 1998/99. New York: Oxford University Press.

Wright, Fergus Chalmers. 1939. Population and Peace: A Survey of International Opinion on Claims for Relief from Population Pressure. Paris: International Institute of Intellectual Co-operation, League of Nations.

Wright, Quincy. 1958. "Population and United States foreign policy," in Philip M. Hauser (ed.), Population and World Politics. Glencoe, IL: Free Press.

Zolo, Danilo. 1997. Cosmopolis: Prospects for World Government. Cambridge: Polity Press. 